\title{
Contract Farming Risks: A Quantitative Assessment
}

\author{
Arkins M Kabungo \\ Eastern Mediterranean University, Northern Cyprus
}

\section{Glenn P Jenkins}

Queen's University, Canada \& Eastern Mediterranean University, Northern Cyprus

Accepted: August 2015

\begin{abstract}
The objective of this study is to identify the key risks facing each of the stakeholders in the export-focused paprika value chain in Zambia. Although a deterministic cost-benefit analysis indicated that this outgrower scheme would have a very satisfactory net present value (NPV), a Monte Carlo analysis using an integrated financial-economic-stakeholder model identifies a number of risk variables that could make this system unsustainable. The major risks include the variability of the real exchange rate in Zambia; the international price of paprika; and the farm yield rates. This analysis points out that irrigation systems are very important for both stabilising and increasing yields. The analysis also shows the limitations of loan financing for such outgrower arrangements when at the sector level it is difficult or even impossible to mitigate the risks from real exchange rate movements and changes in international commodity prices. This micro-level analysis shows how critical real exchange rate management policies are in achieving sustainability of such exportoriented value chains.
\end{abstract}

Key words: Zambia, Monte Carlo simulation, outgrower scheme, risks, paprika smallholder farmers, sustainability

JEL: Q17, 12, H42

\section{Introduction}

During recent decades, agricultural commodity chains in developing countries have experienced substantial restructuring due to changes in both demand- and supply-side factors. On the demand side, factors such as population growth, greater urbanisation, increase in income levels and changes in preferences have reshaped demand for agricultural commodities. On the supply side, factors such as market liberalisation (both national and international); improvements in transportation and logistics; and improvements in technologies have affected the supply chains. These factors have contributed to an increased incidence of contract farming, especially in developing countries (Prowse, 2012).

Smallholder agriculture is the major livelihood of rural and poor families in developing countries and to be more efficient, they need to overcome several major constraints in accessing agricultural commodity chains (Da Silva \& Rankin, 2013). Hazell (2011) indicates that these constraints may include but are not limited to small quantities of production, variable quality, seasonality of rainfall, limited storage facilities, high transaction costs, poor market information, poor contracts and limited ability to meet the high quality requirements of many high value outlets.

Contract farming has been recommended as a tool for poverty reduction in Africa (World Bank, 2007). Within the framework of contract farming, governments and international organisations have proposed non-traditional agricultural exports from Africa as a promising avenue for increasing the incomes of smallholder farmers and alleviating poverty in rural areas (Brüntrup \& Peltzer, 2006). Studies in economic growth (Hidalgo, Klinger, Barabasi \& Hausmann, 2007; Hausmann, Hidalgo, Bustos, Coscia, Chung, Jimenez, Simoes \& Yildirim, 2011) have shown that the chances of success in exporting new agricultural products can be improved if they are related and they use similar factor inputs to the existing products that a country currently produces and 
exports. The types of new crops that have been initiated most successfully through smallholder production are those that are labour-intensive and have relatively low transportation and logistics costs. They often require relatively low investment in storage facilities, and at the farm level are inexpensive to process. Such crops include coffee, cut flowers, cotton, tobacco, groundnuts, fresh vegetables and paprika (Bertow \& Schultheis, 2007). Thus, these crops play a substantial role in promoting sustainable agriculture production, ensuring food security, generating income for farmers and reducing poverty levels in many African countries. However, risks and uncertainties stemming from a wide range of factors are present within the agriculture sector and supply chains.

A variety of risks, such as climatic conditions, natural disasters and uncertain yields owing to unpredictable weather, may affect agriculture outputs (Morton, 2007) as well as uncertainties in prices, high local and international transportation costs (Mamo, 1998), exchange rate fluctuations that affect farm-gate prices (Orden, 2010), escalating processing costs, volatile international market prices and stringent phytosanitary standards (Stevens, 2004). ${ }^{1}$ Vulnerability to certain risks is higher in cases of developing countries and the unpredictable nature of these risks can push smallholder farmers into a deeper state of poverty (Cervantes-Godoy, Kimura \& Antón, 2013).

Zambia is a country which is well-endowed with land and water. While 58 per cent of Zambia's landmass is suitable for agriculture, only 14 per cent of it is cultivated. Zambia is one of the main producers of paprika in southern Africa. Paprika is considered as a major high-value crop for Zambian smallholder farmers who constitute 85 per cent of paprika producers. Studies based on the deterministic assessment of the potential of paprika have recommended it as a promising nontraditional export. According to a study by Langmead (2005), paprika cultivation has the potential to increase the incomes of smallholder farmers as well as to provide them with an opportunity to diversify away from traditional export crops such as cotton and coffee. However, in order to help paprika smallholders to deal with major constraints of accessing agricultural commodity chains, interventions are required by the government of Zambia. Outgrower schemes are one of the possible interventions which attempt to increase participation of smallholders in the production of paprika. Encouraging smallholders to shift to outgrower schemes of high-value crops may increase their income and may improve their economic welfare, but these arrangements have to be analysed by sensitive and in-depth evaluations. In other words, high-value crops may not necessarily translate into high farm profits (Tinsely, 2010) because of potential agricultural risks that may result in high variability of returns for farmers (Glover, 1987; Deininger \& Olinto, 2000; Ponte, 2001).

Langmead (2005) observed that the variability in rainfall, prices, yields and contracts is important to the sustainability of the paprika value chain in Zambia, but he did not quantitatively show how these risks could affect the viability of smallholder farmers and other players in the value chain. While potential risks facing stakeholders in non-traditional export crop production and marketing have been identified in the relevant literature, as far as we are aware no attempt has been made to assess quantitatively the relative magnitude of these risks. Without a quantification of the potential risks, it is very difficult to design mitigation strategies that will have a high probability of success.

The aim of this study, therefore, is to evaluate quantitatively the relative impact of the risks associated with growing paprika under an outgrower arrangement in Zambia. In this case, the ultimate destination of the crop is the European Union. We assess the relative impact of the various sources of risk through a Monte Carlo simulation of an integrated financial-economicstakeholder model of smallholder paprika production, processing and export. The model is used to assess how the key risks alter the attractiveness of the operation from the perspective of the domestic stakeholders in the export value chain. Finally, we identify the policies that need to be in place in order to enhance the prospects for the sustainability of the paprika value chain in Zambia.

\section{Paprika outgrower schemes in Zambia}

Historically, the agricultural sector in Zambia has recorded an average annual growth of 2.5 per cent, which is significantly below the population growth rate of 3.7 per cent. This sector has performed poorly because of: 
1) Poor economic planning of the country; priority is given to the mining sector.

2) Over-dependency of smallholders to rainfed farming.

3) Lack of access to financial resources for smallholder agricultural development.

4) Inadequate extension and regulatory services from government.

Recently, due to an increase in the contribution of the agricultural sector to the GDP up to 25 per cent, the Government of Zambia has paid more attention to it. Undoubtedly, greater productivity in this sector can make a more significant contribution to the economy of Zambia. Outgrower schemes are considered as potential tools for this purpose. Hence, the government has started to allocate more resources for schemes in order to achieve sustainable economic growth and to reduce the incidence of poverty in smallholder farm areas. This study evaluates an outgrower arrangement for paprika that seeks to provide market linkages between smallholders and the European markets in the processed product, through the operators acting as intermediaries. Such arrangements can give smallholder farmers the opportunity to export paprika. To achieve this goal, the contract farming scheme should be designed properly in order to be able to mitigate the risks. It should address the issues that may militate against the benefits and deter smallholders from participating in the paprika outgrower scheme. The benefits generated are a function of yield rates, real exchange rate and the international price of paprika.

The weather conditions in Zambia are such that they enable the country to produce paprika under both rainfed and irrigation farming conditions, but the expected yields are very different. Therefore, in designing an outgrower scheme for paprika, a critical issue is the relative amounts of rainfed cultivation and irrigation that should be included in the scheme. Rainfed cultivation is characterised by much lower yields combined with much greater risks due to uncertainty of the rains, which greatly reduces its potential value for poverty reduction. According to Langmead (2005), small-scale paprika farms in Zambia have different yield classes. As the yield classes rise, farmers increasingly use more fertilizers, managed more efficiently, and some use irrigation. Irrigation is likely to be a key mitigating factor in managing the risk of yield variability, as well as being a major determinant of the average yield.

A quantitative analysis of the relationship between rainfall, crop yields and sector performance will provide critical information on the degree to which investments in irrigation are required before either the smallholders or the operator is able to accept the residual risk of the project's performance.

Due to the dependency on copper exports and the price of copper, the real exchange rate of the Zambian kwacha/US\$ has been highly variable over time. Since farmers' revenues stem from US\$ denominated sales of paprika in international markets, fluctuation in the foreign exchange rate is a critical factor for the scheme. A challenge for the design of policies to develop such an export crop is to understand the nature and magnitude of the likely risks arising from variability of export prices and the real exchange rate, and to design strategies to mitigate these risks.

In the financial model used to conduct this analysis the market exchange rate used to convert foreign into local currency is projected over time as the projected real exchange rate times the projected domestic price index divided by the projected price index for the foreign country. These projected price indices are constructed to be consistent with the assumptions factored into the model for the rate of domestic and foreign inflation. This is the well-known purchasing power parity (PPP) exchange rate assumption. This relationship is likely to hold reasonably well in the long run, but in the short term the market exchange rate will usually vary a great deal from the projected exchange rate constructed, using the PPP assumption. Hence, in our analysis the real exchange rate risk comes from year-to-year deviations of the actual market exchange rate from the projected PPP exchange rate.

\section{Structure of analysis}

An integrated cash flow (resource flow) model is used to evaluate the net benefits that accrue to the smallholder farmers and the operator. Smallholder farmers in Zambia are those who work less 
than two hectares of land in subsistence agriculture. The smallholder farmers and the operator work on a contractual basis using an outgrower arrangement that assigns responsibilities to each party. The operator may be an independent crop-sponsoring organisation or an agribusiness firm that 'off-takes' and processes the crop for sale in midstream and downstream markets.

The main focus of this paper is on the risks associated with the financial cash flows of the project and the financial relationships between the main stakeholders; namely, the operator, the smallholder and the government. However, the overall economic impact is critical in determining if there is a net surplus between the economic benefits and the economic resource costs of the project after the costs of an acceptable level of risk mitigation have been accounted for. After a financial cash flow model has been built and the base case financial analysis completed, an economic analysis will indicate the degree of economic surplus that could potentially be realised and to which stakeholders the surplus will accrue.

The operator is the nucleus of the outgrower value chain, playing the critical roles of both the financial and the market intermediary. As a market intermediary, the operator provides a link between the international export markets and the Zambian smallholder. The operator also provides extension services to the smallholder farmers in addition to those provided by the local government. $^{2}$

In the scheme analysed in this paper, the operator generates revenues from the export sales of processed paprika in the European market. The revenue from the commodity sales is determined by the world price fetched by Zambian paprika at the European point of import. The operator's cash flow costs are the expenses associated with off-taking the unprocessed paprika crop from the farmers as well as processing and transporting it. ${ }^{3}$ As a financial intermediary, the operator bears the administrative overhead burden of sourcing credit from commercial banks to finance the working capital requirements of the outgrower smallholder farmers. The credit is advanced in kind to the smallholder farmers at a cost to the farmer that includes the borrowing costs of the operator adjusted for a margin that reflects the cost of processing the credit and the anticipated default risk of the farmers. ${ }^{4}$ In the model, this credit-processing cost is set at such a level that the net financial position of the operator is not adversely affected, unless the rate of credit default deviates from the anticipated target. ${ }^{5}$ The net earnings of the operator are subject to income tax, while the valueadded tax (VAT) paid by the operator on purchased inputs is refunded through the zero rating of export sales. Delays in the collection of revenues and making payments for operating expenses, as well as the dynamics of the cash flow over time, have been captured by the magnitude of working capital in the model as determined by the changes in cash balances, accounts receivable and accounts payable over time. The algebraic structure of the model is described in the Appendix to this article.

\subsection{The smallholder farmers}

The cash inflows of the smallholder farmers are the farm-gate sales of the paprika crop to the operator that occur at the end of each cultivation cycle. The outflows of this group of farmers are the capital costs associated with investment in irrigation equipment and market support infrastructure, such as depot and storage facilities. Other outflows are the cost of agricultural inputs such as fertilizer, packaging materials, electricity, crop management activities, irrigation equipment and maintenance costs. The farmers also incur expenses for land preparation. A key non-cash aspect of the smallholder farmers' costs, and an important determinant of the incentive for the farmer to cultivate the crop, is the opportunity cost of the land and of the time that is spent growing cash crops instead of the staple food crop. This opportunity cost is expressed as the net value of the maize food crop that would be grown in the absence of a cash crop such as paprika. Without the proposed scheme, the majority of the farmers in Zambia would plant maize for their own consumption using the traditional means on rainfed land, the so-called "low-input, lowoutput" cultivation method such as the Chitemene system. ${ }^{6}$ 


\subsection{The outgrower scheme}

In order to support such arrangements, the government of Zambia and multilateral financial institutions have agreed in principle to provide financial assistance to farmers. In order to find out whether the scheme is able to use these funds efficiently, we estimate the cash flows from the perspective of the entire outgrower scheme arrangement by incorporating the financing provided by multilateral donors and the host government. All the investments, production, processing and transportation costs of the smallholder farmers and the operator are deducted from the value of sales. From the outgrower scheme perspective, all intermediate sales of paprika and transactions between farmers and the operator are viewed as transfers and are not included in the statement.

In the estimation of the cash flows, the inflation rates in Zambia and abroad and the changes in exchange rates have been consistently taken into account, assuming that purchasing power parity provides a benchmark for the market exchange rate over the long term. ${ }^{7}$ The cash flow projections are expressed in units of domestic currency. The investment and operating costs have been classified as either tradable or non-tradable. The latter includes such items as local labour costs, construction services and domestic transportation services. The prices of tradable items are expressed in dollars and then converted into local currency values (Zambian kwacha, ZMK ${ }^{8}$ ) at the projected market exchange rate for each period. Projections over time are made first in nominal values, and are then converted into their real values by applying the appropriate price indices.

\section{Base case analysis and results}

We estimate the model, using cost and price data expressed at the 2012 price level. The year 2012 is also taken as the base year of our analysis for the calculation of the NPVs, and the average annual rate of inflation over the period of analysis is assumed to be 9 per cent. The market exchange rate for 2012 is taken as 5,200 ZMK/US\$. The nominal exchange rate is projected to change in future years based on the relative price index of Zambian inflation and the US price index. The latter is assumed to increase at an annual rate of 2.5 per cent. The outgrower scheme is focused on 2,500 smallholder farmers, each assumed to dedicate one hectare of land to the cultivation of paprika. The total number of hectares is 2,500 , with 1,500 under rainfed cultivation and the rest irrigated. Starting with a core group of 300 farmers, the 2,500 smallholder farmers are gradually incorporated into the scheme over a period of five years. Since they play a key role in the outgrower scheme, the farmers are given some training from the government. ${ }^{9}$ For the purposes of understanding the financial viability of the actors in the value chain, we evaluate the operations for a period of ten years.

The base case employs a yield rate of $900 \mathrm{~kg}$ per hectare under rainfed and 2,500 $\mathrm{kg}$ per hectare under irrigated cultivation (Langmead, 2005). It is assumed that the price of the farm-gate crop is 17 per cent of the export price. ${ }^{10}$ We assume in the deterministic base case that there is a constant yield rate over the life of the operation. ${ }^{11}$ Smallholder farmers' operating costs are based on crop budgets obtained from the government (Salami, Kamara \& Brixiova, 2010).

In order to determine the appropriate financing arrangements for such a scheme, the analysis is initially carried out on the assumption that a commercial bank loan is extended to the operator to finance all of the investment and working capital outlays incurred by the farmers. The operator will, in turn, use this financing to make loans to the farmers and will recover the loans and interest charges when the farmers sell their product to the operator. The US\$-denominated commercial bank loans to the operator for farm inputs and infrastructure are made at a nominal interest rate of 8 per cent. The loan is then re-lent to the smallholder farmer groups with a margin of 4 per cent, reflecting the anticipated credit risk of default and non-repayment.

The processing costs borne by the operator are $60 \mathrm{US} \$ /$ ton, including the incremental investment cost for additional processing capacity. Other key costs for the operator are as follows:

5) Domestic transportation costs: These cover the collection of paprika from the farmers, and are estimated to be $30,000 \mathrm{ZMK} / \mathrm{ton} / \mathrm{km}$. It is known that most of the smallholder farmers are located within a distance of $30 \mathrm{~km}$ from the operator. 
6) Processing costs: These include expenses incurred for electricity, hexane, mineral oil, water, wages, etc. Factory labour costs are estimated to be $1,600,000 \mathrm{ZMK} /$ ton, while the cost of raw materials is estimated to be $1,200 \mathrm{US} \$ /$ ton, at 2005 prices.

7) International transportation costs: Although the domestic transportation costs are quoted in Zambian kwacha, international transportation costs are paid in US dollars. These are estimated to be $500 \mathrm{US} \$ /$ ton at 2005 prices (ECI Africa and DAI PESA, 2004).

\subsection{Base case results}

Given the model's assumptions, the base case result for the operators is a positive NPV of ZMK 101.4 billion at 2012 prices using a real rate of discount of 15 per cent. A set of annual debt service coverage ratios (ADSCRs) are estimated in order to assess the ability of the operator to pay back interest charges and principal on the commercial bank loan. ${ }^{12}$ As shown in Table 1 , the minimum ADSCR is $1.23 \mathrm{x}$ the annual service in 2013, and for the rest of the years it is in the range $1.50 \mathrm{x}$ to $3.00 \mathrm{x}$, with an average of $2.12 \mathrm{x}$. With the exception of 2013 , it would appear that the operator would have an adequate cash flow to cover the amount of debt service due. However, the operator's ability to repay the credit is directly linked to the farmers' ability to supply the crop as contractually agreed. If a significant number of farmers default for any reason on the delivery of the anticipated volumes of paprika or do not make their credit repayments, the operator is also likely to have trouble in meeting his loan repayment obligations to the bank.

Table 1

Operator and smallholder farmers' ADSCRs

\begin{tabular}{|l|c|c|c|c|c|c|c|c|c|c|c|}
\hline & NPV & $\mathbf{2 0 1 3}$ & $\mathbf{2 0 1 4}$ & $\mathbf{2 0 1 5}$ & $\mathbf{2 0 1 6}$ & $\mathbf{2 0 1 7}$ & $\mathbf{2 0 1 8}$ & $\mathbf{2 0 1 9}$ & $\mathbf{2 0 2 0}$ & $\mathbf{2 0 2 1}$ & $\mathbf{2 0 2 2}$ \\
\hline Operator & ZMK 101.5 bn & $1.23 \mathrm{x}$ & $1.62 \mathrm{x}$ & $1.88 \mathrm{x}$ & $2.06 \mathrm{x}$ & $2.10 \mathrm{x}$ & $2.25 \mathrm{x}$ & $2.33 \mathrm{x}$ & $2.45 \mathrm{x}$ & $2.59 \mathrm{x}$ & $2.72 \mathrm{x}$ \\
\hline Smallholder farmers & ZMK 104 bn & $1.65 \mathrm{x}$ & $1.08 \mathrm{x}$ & $1.10 \mathrm{x}$ & $1.24 \mathrm{x}$ & $1.24 \mathrm{x}$ & $1.26 \mathrm{x}$ & $1.37 \mathrm{x}$ & $1.51 \mathrm{x}$ & $1.67 \mathrm{x}$ & $1.81 \mathrm{x}$ \\
\hline
\end{tabular}

In the base case (using a real discount rate of 10 per cent) for the situation of all the smallholders as a group, the NPV amounts to ZMK 104 billion, over and above what they could earn by growing maize. This result suggests that the participating smallholder farmers would be able to recover all their investment, operating and credit costs as well as earn a return on equity of more than 10 per cent in real terms. This result is quite plausible by regional standards as the paprika project links the rural communities to the modern market economy. The ADSCRs are an indication of the ability of smallholder farmers to generate sufficient net cash to cover the opportunity cost of growing a cash crop rather than just subsistence maize cultivation, and to cover the input credit repayments to the operator. The resulting ratios are greater than $1.0 \mathrm{x}$. This means that, on average, the farmers are expected to be able to cover their opportunity and input costs, and in addition, to service their credit repayments. The minimum value of the annual available net cash flows occurs in 2014, when the ADSCR is $1.08 \mathrm{x}$ times the credit repayment to the operator.

Despite the attractiveness of these outcomes, account needs to be taken of the variability of the value of the input and output parameters of the cash flow model. There remains the question of what the probability is that farmers would have sufficient cash each year to recoup their opportunity costs and be able to repay their loans to the operator. The next section addresses the question of the impact of variability on the net cash flow results of each of the stakeholder groups.

\subsection{Economic analysis of the base case}

As paprika is sold internationally, its increased production has little impact on domestic consumption of the product. Zambia, however, has a full menu of taxes on inputs, and on formal sector labour. In addition, there is a premium on the foreign exchange of 7.25 per cent (Kuo, Salci \& Jenkins, 2014) that is applied to both the outflows of foreign exchange used to purchase tradable inputs and the inflows of export receipts. The premium in this case reflects the indirect taxes that will be reduced or generated, depending on the project's use or production of foreign exchange. 
Economically, three groups of stakeholders benefit from this paprika outgrower scheme: the smallholder farmers; the operators; and the government of Zambia. Our results show that this scheme results in a positive economic NPV of ZMK 240 billion using the economic opportunity costs of capital of 15 per cent real for Zambia. The operator and the farmers are shown to gain a NPV of ZMK 101.5 and ZMK 104, respectively. The present value of the net tax revenues accruing to the government amounts to ZMK 14.6 billion. From a strictly cash flow point of view the government is expected to receive these additional revenues so that it would be able to provide some financial support to this scheme without causing a net drain on the budget.

\section{Sensitivity analysis}

The results from the evaluation of the farmers' and operators' participation in the outgrower scheme suggest that the scheme is attractive from the perspective of both the smallholder farmers and the operators. The main drawback of the base case scenario is the implicit assumption that the price and cost values, inflation rates, exchange rates and yield rates, as well as other parameters used in assessing the viability of the outgrower operation, are known with certainty. The implication is that the estimated ADSCRs and NPVs are also certain and therefore deterministic. This deterministic base case model of the financial analysis does not take into account the uncertainties and fluctuations that the scheme is expected to encounter over its life cycle. The long-term financial viability and sustainability of the scheme is largely determined by the volatility of a number of key variables.

In this study we conduct a series of sensitivity tests for key variables in the value chain, and evaluate the negative impact of these changes on the NPV, along with their impact on the minimum and average ADSCR values. Based on the sensitivity results, the key risk variables that could adversely affect the value chain are those that have a pronounced impact on the NPVs and ADSCRs. Specifically, the impact of yield rates, real exchange rate, the price of paprika in Europe and the cost of international transportation tend to have the greatest impact on both the operator and smallholder farmers.

Yield rates, $\gamma$, affect the amount of crop, $Q^{f g}$, that is sold by the farmer to the operator. In practice, the farm yields of the smallholder farmers are affected by a wide variety of factors ranging from agronomic conditions to weather patterns. The availability of rainfall is critical for the cultivation of paprika in non-irrigated areas. The exchange rate is a major determinant of the kwacha value of the export earnings and of the kwacha cost of the tradable inputs used in the operation. In the model, non-tradable items are valued directly in kwacha and their prices are not directly affected by the movements of the ZMK/US\$ exchange rate. The cost, insurance and freight (CIF) price (in Europe) of the processed paprika is affected not only by the exchange rate but also by changes in its real or relative prices owing to global shifts in demand and supply of paprika and its close substitutes. As the output of this operation is not large enough to affect the world paprika price, from the perspective of Zambia this outgrower scheme takes the world price as an exogenous variable. Similarly, fuel prices, international transportation costs and material processing costs are tradable items affected by the dynamics of the exchange rates and global markets.

\section{Monte Carlo risk analysis}

The above analysis helps to identify variables that are important determinants of the variability of financial indicators such as the ADSCR and the NPV. However, it must be noted that in a sensitivity analysis the impact of varying each variable is assessed while the values of the other variables are fixed. There is no simultaneity in the assessment. In reality, many risk variables are changing at the same time and they are often correlated. Therefore, to gain a better understanding of the impact on the financial performance of the operation we employ a Monte Carlo simulation analysis. Monte Carlo simulations provide one of the most practical methods of approximating the 
dynamics and uncertainties of the real world. The risk analysis repeats the simulation of the financial analysis many times using distributions of the values of the most sensitive and uncertain variables affecting the operation. These results are then analysed statistically to arrive at a distribution of the possible financial outcomes for the operator and the smallholder farmers, and the probabilities of their occurrence. ${ }^{13}$

For this study, we develop probability distributions for risk variables as follows:

8) Yield rate: The yield rate under rainfed cultivation is likely to be affected by the variability in the temperature, rainfall and level of use of inputs. We assume that the level of agricultural inputs of the smallholder farmers is sufficiently available and financed via the credit mechanism, so they will not constrain the yield rates. However, crop yields are likely to be affected by climate variation such as changes in precipitation, temperature, sunshine and other meteorological factors (Sakaida, 1993). A combination of temperature and other meteorological factors has a direct impact on the rainfall, which in turn affects the crop yield level. For the simulation, the yield rate in any cultivation period will be obtained from a distribution defined as:

Eq. $1 \quad \gamma_{t}=900(1+\lambda)$

The distribution of the yield rates is based on observations of yields of smallholder farmers in Zambia (Langmead, 2005).

9) Real exchange rate: This is a factor that has a direct impact on the domestic currency values of all tradable items in the model. In the projection of the real exchange rate for the base case, we have assumed that it remains constant at 5,200 ZMK/US\$ over the evaluation period of the operation. The risk analysis model adjusts the predicated real exchange rate by using the stochastic random error $\eta$. The random component is based on the historical kwacha/dollar exchange rate for 1986-2010 (World Bank Development Indicators, 2012), and captures all the deviations from the trend of the real exchange rate with a mean of zero and a standard deviation that defines the riskiness inherent in the exchange rate.

Eq. $\left.2 \quad F x_{t}=\overline{F x_{t}(1}+\eta\right)$

10) CIF price of paprika: The random error of mean of zero, $\varphi$, is applied to the CIF prices of paprika. This is based on the historical producer prices of green pepper sold in Europe (FAO, 2012).

Eq. $3 \quad C I F_{t}=\overline{C I F_{t}}(1+\varphi)$

11) Two other variables that have been modelled include the investment cost overruns ${ }^{14}$ on all the farmers' and operators' capital costs, and the price of international transportation. ${ }^{15}$ Table 2 gives a summary of the statistics of the underlying distributions of the risk variables.

Table 2

Statistics of custom distributions for risk parameters

\begin{tabular}{|l|c|c|c|c|c|}
\hline \multicolumn{1}{|c|}{ Risk statistics } & Cost overrun & Exchange rate & CIF paprika price & Yield rate & Freight cost \\
\hline Mean & $0 \%$ & $0 \%$ & $0 \%$ & 899 & $0.0 \%$ \\
\hline Median & $1 \%$ & $-2 \%$ & $-1 \%$ & 898 & $-0.2 \%$ \\
\hline Standard Deviation & $7 \%$ & $26 \%$ & $23 \%$ & 369 & $0.8 \%$ \\
\hline Variance & $0.49 \%$ & $6.7 \%$ & $5.4 \%$ & 136067 & $0.0 \%$ \\
\hline Skewness & 0.22 & 0.45 & 0.35 & 0.02 & $18.8 \%$ \\
\hline Kurtosis & 1.86 & 2.03 & 2.96 & 0 & 1.89 \\
\hline Coeff. of Variability & 120 & -160 & -117 & 250 & -197 \\
\hline Minimum & $-10 \%$ & $-36 \%$ & $-44 \%$ & 1570 & $-1.3 \%$ \\
\hline Maximum & $20 \%$ & $54 \%$ & $80 \%$ & 1320 & $1.5 \%$ \\
\hline Range Width & $30 \%$ & $90 \%$ & $123 \%$ & 4 & $2.8 \%$ \\
\hline Mean Std. Error & $0 \%$ & $0 \%$ & $0 \%$ & & $0.0 \%$ \\
\hline
\end{tabular}




\section{Simulation results}

Using the Crystal Ball Software (Decisioneering Inc., 2005), a total of 10,000 simulations are run in order to estimate the NPVs and ADSCRs for the operator and the smallholder farmers. The base case simulations are carried out using the assumption that any risks that are likely to affect the cash flows or benefits pre- and post- farm gate are borne by each party under a constraint that does not allow any party to shoulder a greater share of the risk for the benefit of the others. In this scenario, there are no restrictions in the model, and therefore the transmitting mechanism for risks will be the share of the farm-gate price and the level of volumes of the paprika crop produced. Unlike the base case outcomes above, the outputs of the simulation are distributions of the NPVs and ADSCRs. Table 3 shows the means, the standard deviations and the probabilities of default for the distributions of the ADSCRs and the NPVs.

The mean, standard deviation and probabilities of the distributions of the NPVs (Table 3, column 11) are based on the assumption that the scheme will survive the year-to-year fluctuations in the net cash flow of each party concerned. However, on a year-by-year basis, the viability of the scheme is dependent on the ability of both the operator and the smallholder farmers to meet their debt obligations. Analysing the distributions of the ADSCRs is therefore important in understanding the commercial and long-term sustainability of the value chain for paprika as a nontraditional export.

Table 3

Summary of simulation results

\begin{tabular}{|c|c|c|c|c|c|c|c|c|c|c|c|c|}
\hline \multicolumn{2}{|r|}{ Column } & 1 & 2 & 3 & 4 & 5 & 6 & 7 & 8 & 9 & 10 & 11 \\
\hline \multicolumn{2}{|r|}{ Year } & 2013 & 2014 & 2015 & 2016 & 2017 & 2018 & 2019 & 2020 & 2021 & 2022 & FNPV \\
\hline \multicolumn{2}{|r|}{ Operator } & \multicolumn{11}{|c|}{ ADSCRs } \\
\hline 1 & Base case & 1.23 & 1.62 & 1.88 & 2.06 & 2.1 & 2.25 & 2.33 & 2.45 & 2.59 & 2.72 & 101.5 \\
\hline 2 & Mean & 1.11 & 1.53 & 1.79 & 1.96 & 2.01 & 2.15 & 2.24 & 2.35 & 2.48 & 2.6 & 101.4 \\
\hline 3 & Median & 1.1 & 1.51 & 1.75 & 1.92 & 1.97 & 2.09 & 2.17 & 2.27 & 2.39 & 2.51 & 100.3 \\
\hline 4 & Standard deviation & 0.69 & 0.64 & 0.65 & 0.67 & 0.67 & 0.69 & 0.76 & 0.84 & 0.94 & 1.02 & 22 \\
\hline 5 & Prob. ADSCR<1 & 0.45 & 0.19 & 0.1 & 0.1 & 0.05 & 0.03 & 0.03 & 0.03 & 0.04 & 0.04 & \\
\hline \multicolumn{2}{|c|}{ Smallholder farmers } & \multicolumn{11}{|c|}{ ADSCRs } \\
\hline 6 & Base case & 1.65 & 1.08 & 1.1 & 1.24 & 1.24 & 1.26 & 1.37 & 1.51 & 1.67 & 1.81 & 104 \\
\hline 7 & Mean & 1.81 & 1.12 & 1.12 & 1.24 & 1.24 & 1.25 & 1.36 & 1.5 & 1.66 & 1.81 & 100 \\
\hline 8 & Median & 1.61 & 1.01 & 1.03 & 1.14 & 1.15 & 1.16 & 1.27 & 1.4 & 1.55 & 1.67 & 99 \\
\hline 9 & Standard deviation & 0.96 & 0.57 & 0.52 & 0.54 & 0.53 & 0.52 & 0.58 & 0.65 & 0.72 & 0.8 & 12 \\
\hline 10 & Prob. ADSCR<1 & 0.21 & 0.49 & 0.48 & 0.39 & 0.37 & 0.37 & 0.29 & 0.23 & 0.18 & 0.14 & \\
\hline
\end{tabular}

${ }^{*}$ The probabilities for the NPVs were tested to see whether they are less than zero. In the two cases, the probabilities are almost zero. This is also evident from the standard deviation of the NPVs when compared to the deterministic NPVs.

The means of the ADSCRs lie only slightly below the deterministic base case ratios. This observation is to be expected, since the base model is constructed based on the average values of the input assumptions. From Table 3, it can be seen that the standard deviation of the operator's ADSCRs increases over time from $0.69 \mathrm{x}$ to $1.20 \mathrm{x}$, indicating that the riskiness of the cash flow increases steadily over the life of the operation. The volatility in the cash flows increases with time, despite the low ADSCRs seen in the earlier periods when the operator's cash flows are highly stressed owing to its on-going investment. In Figure 1, we plot bounds of two standard deviations below and above the base ADSCRs. The lower bound of two standard deviations below the mean has a value for the ADSCR below 0.0x (in 2013) and a maximum of 0.87x. The upper bound of two standard deviations above the mean is consistently above $2.50 \mathrm{x}$ over the life of the operation. Figure 2 presents the probability of default, which in this case is the measure of the chance that the ADSCRs will fall below the threshold of $1.00 \mathrm{x}$. While the earlier years are characterised by potentially low ADSCRs with low threshold margins above 1.00x and low standard deviations, the likelihood of default on the loans to the bank in these early years is 
relatively higher. The probability of default significantly decreases over the life span of the operations, despite the increase in variability over the same period.

Figure 1

Summary of the statistics for the distributions of ADSCRs for the operator

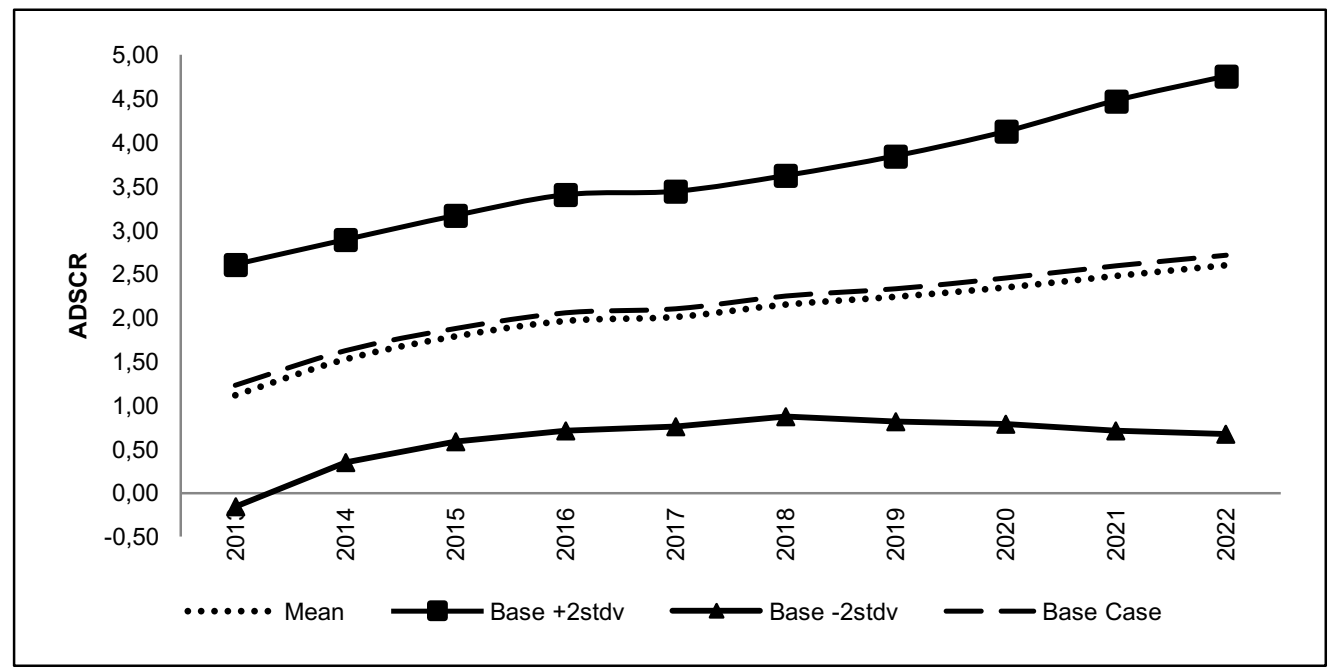

Figure 2

Probabilities of loan default for operator

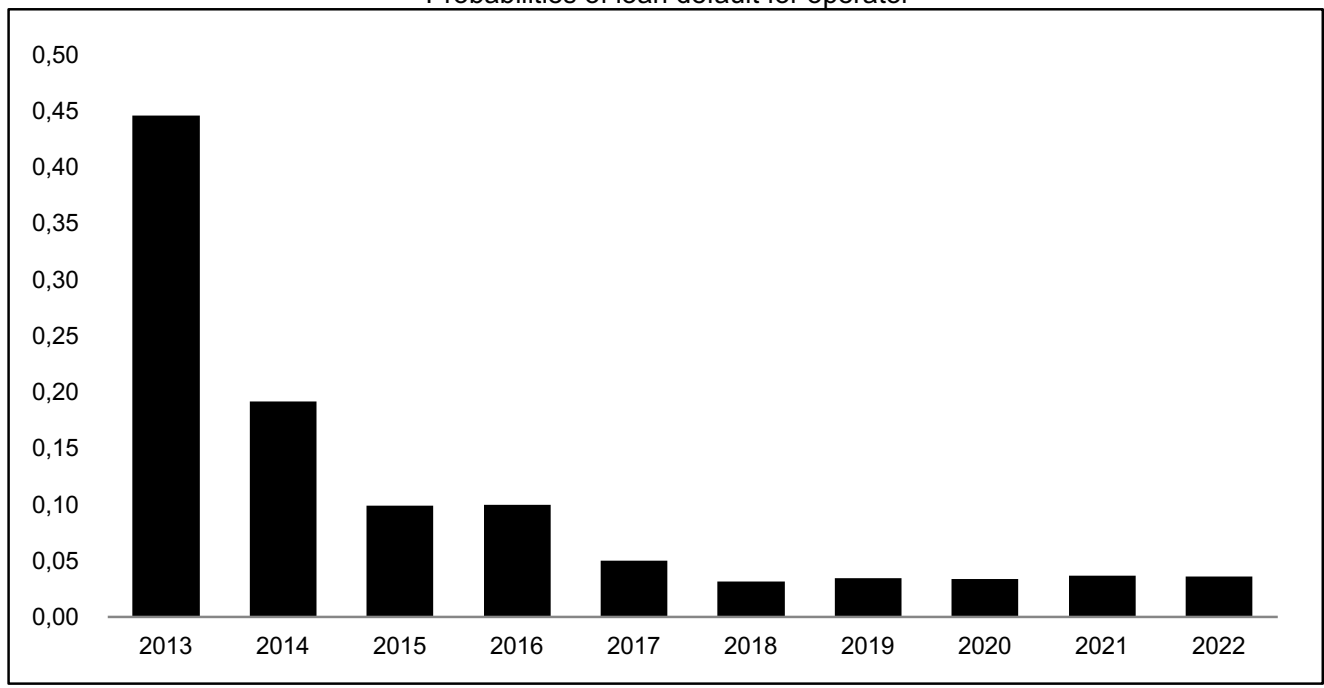

The statistics for the simulations for the smallholder farmers are presented in Table 3 and summarised in Figure 3. From Table 3, we see that the expected values of the ADSCRs and the NPVs are again close to the base case results.

The profile of the statistics for the distribution of the ADSCRs for the smallholder farmers is shown in Figure 3. The projections of the ADSCRs for two standard deviations below and above the base ADSCRs clearly indicate a high downside risk with ADSCRs that are persistently below 1.0x over the operating period of the scheme. The ADSCRs that are two standard deviations below the mean have a minimum ratio of $0.0 \mathrm{x}$ with a maximum value of only $0.22 \mathrm{x}$. These values are significantly lower than those observed in the case of the operator, which indicates that for the same level of duress, the smallholder farmers experience more risk. This is also evidenced by the 
standard deviation values of the ADSCRs for the smallholder farmers that have a minimum of $0.52 x$ and maximum of $0.96 x$ (Table 3 , row 9).

Figure 3

Statistics of distributions of ADSCRs for smallholder farmers

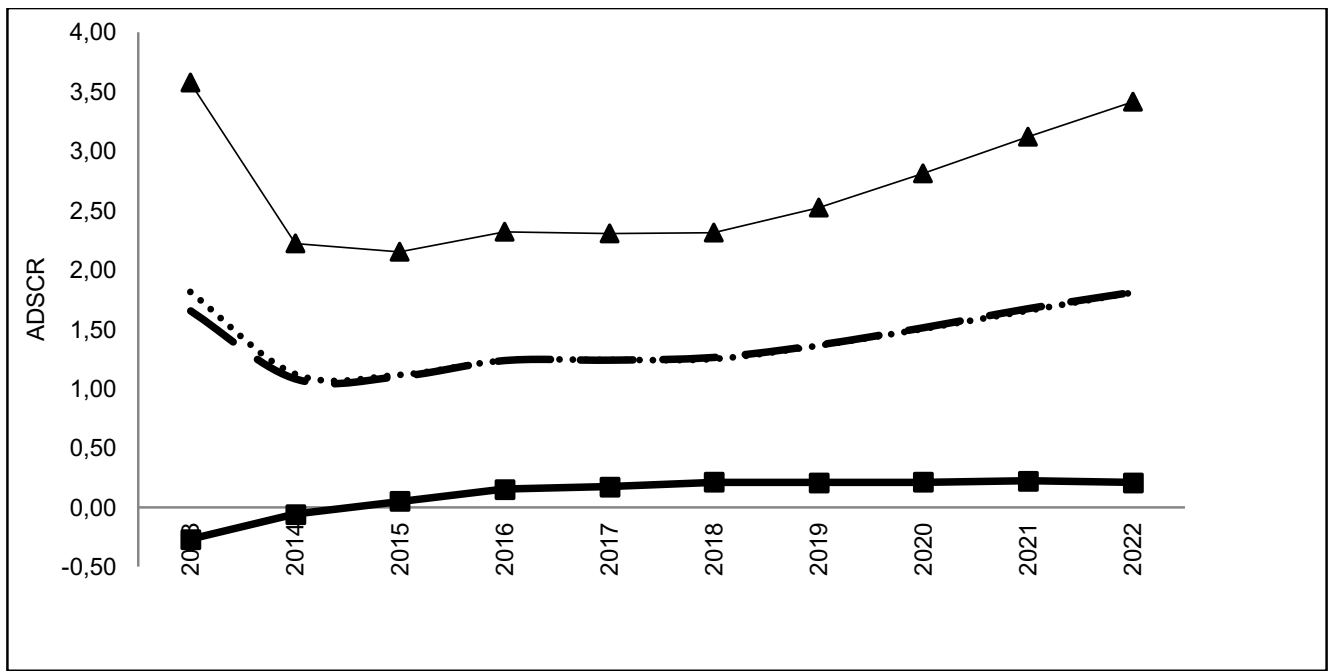

The upside remains above $2.00 \mathrm{x}$, and steadily increases over the life of the project. The probabilities of default (Figure 4) for the smallholder farmers are highest in the early years when the smallholder farmers are making their investments, but decreases gradually from 2014. Despite this decrease during the operating period, the probabilities of default remain consistently high. In 2014 , when the ratio is lowest, the probability of default is 0.49 . The average probability of default stands at 0.30 , which confirms a huge downside risk that the ADSCRs are likely to be below the threshold level of $1.00 \mathrm{x}$.

Figure 4

Probabilities of loan default for smallholder farmers

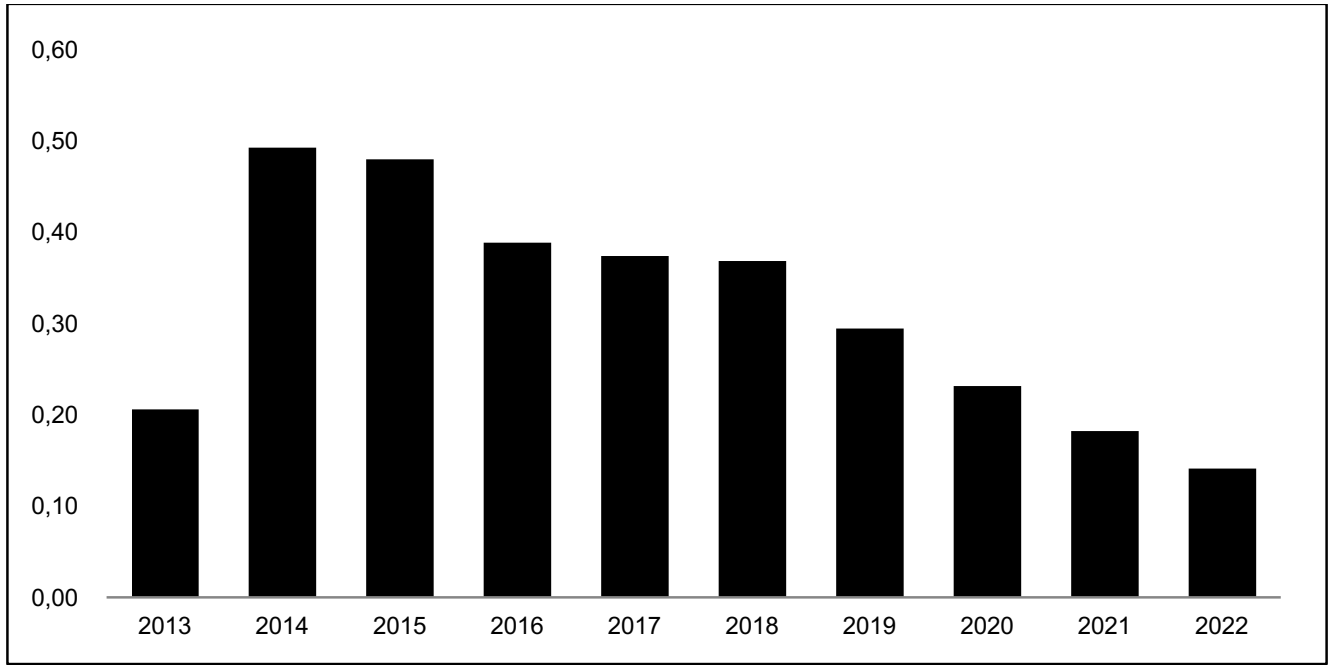

The risk analysis, based on the five key assumptions identified from the sensitivity testing process, indicates that the variability and uncertainty in the key risk variables are likely to alter the perception of the attractiveness of the outgrower operation. Despite the promising potential for the 
operator and the smallholder farmers, there is an inherent downside risk that the benefits of the deterministic case cannot be realised. The results show that the downside risks are so large that it is likely that the operator will not be liquid enough to meet its loan obligations. The volatility of the results is even greater for the smallholder farmers' cash flows. This casts a significant shadow of doubt on the veracity of the deterministic outcomes of the outgrower arrangement.

This analysis points to the inherent liquidity problems that arise when a scheme is so heavily financed through commercial loan finance. Even in this case the terms of the loan are based on those offered to a commercial business operator, not the typical high cost of credit that is available to smallholder farmers. Serious repayment problems are likely to arise even if the overall activity is expected to yield a positive NPV.

As part of the simulation results, we compare the contribution to the overall variation of the five risk variables. The Tornado charts for the ADSCRs for the operator (2014) and smallholder farmers (2013) are shown in Figure 5. The years 2014 and 2013 are selected because they have the lowest ratios for the operator and smallholder farmers respectively and cover the years affected by the downside risk first. Moreover, 2013 has the highest standard deviation for the smallholder farmers.

Figure 5

Tornado charts of contribution to variability

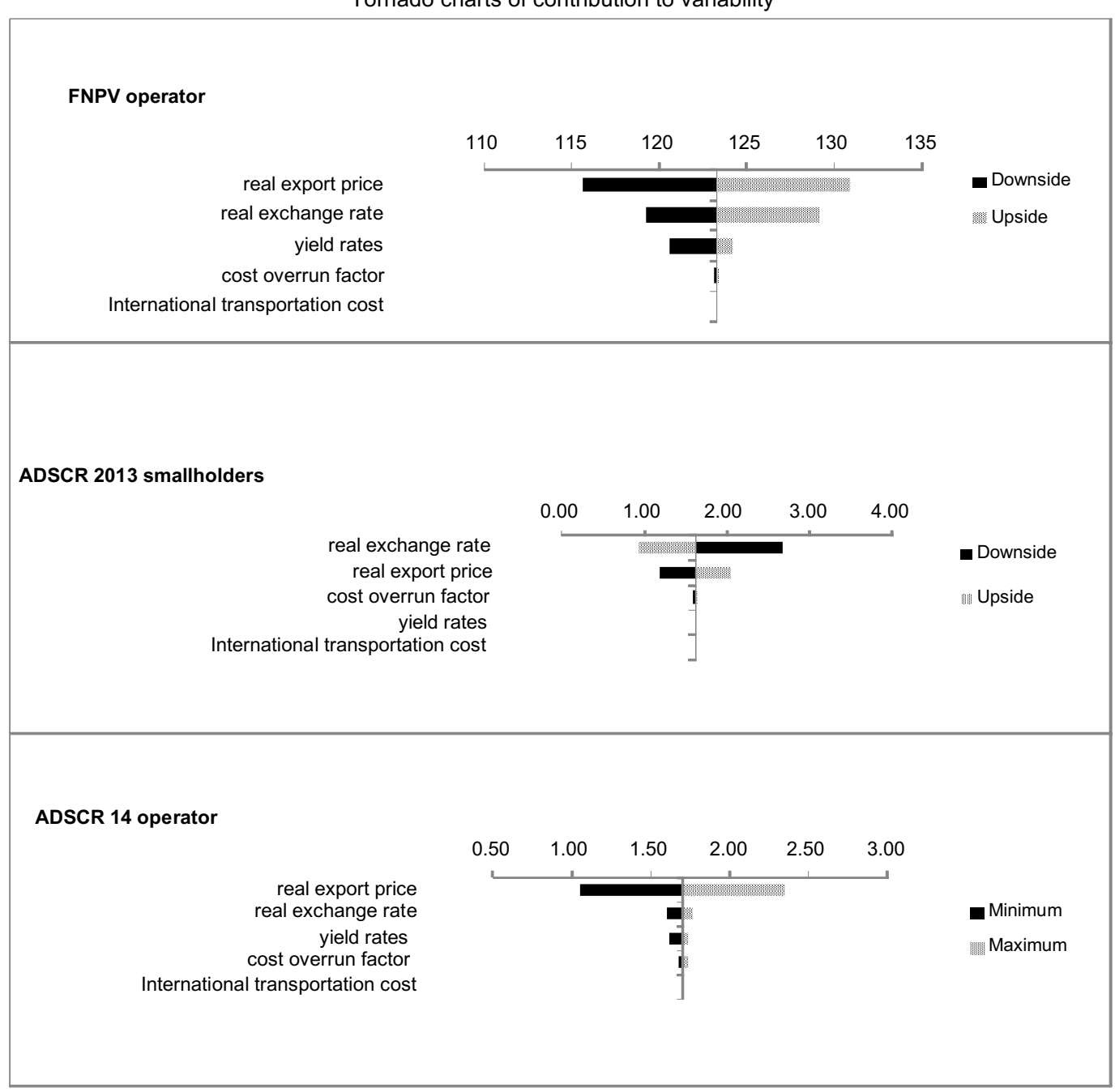


The variability in ADSCR for the operator is largely explained by fluctuations in the real export price. The variability of the real exchange rate tends to affect the smallholder farmers most. Similar charts (not presented) obtained for the ADSCRs in other years consistently show that the contribution to variability is largely explained by the real export price and real exchange rate variability. The yield rate ranks third as a major contributor to variability. This is not surprising given the difficulty that the Zambian government has had over time in managing the country's real exchange rate. The fluctuations in the price of Zambia's major export, copper, and the country's weak macroeconomic management have created wide fluctuations in the real exchange rate between the Zambian kwacha and the US dollar.

\section{Conclusion}

The analysis carried out in this study identifies the dangers of designing an export crop program in a country without the relevant risk mitigation policy measures in place. The ability of the overall scheme to manage the wide year-to-year fluctuations of the net cash flows is critical for the continued participation of the smallholder farmers as well as the financial survival of the operator.

The results of our deterministic analysis indicate that both the operator and the smallholder could benefit from exporting paprika to international markets. This is substantiated by the Monte Carlo risk analysis that generates an expected financial net present value that is very close to the deterministic case. Each of the stakeholders appears to be able to earn a very attractive return on their investment as well as generate cash flows that are sufficient to repay their loan obligations. These conclusions are similar to the previous studies that are reported in the literature on paprika and similar crops (Langmead, 2005).

However, risk simulation results reveal that as the project is now structured, both the operator and the smallholder farmers are likely to experience huge downside risks arising from short term liquidity problems that could erode the outgrower scheme's long-term sustainability. The level of downside risk is higher for the smallholder farmers than for the operator. The cash flow constraint faced by the farmer arises to a large degree from the need to repay the loan each year after harvesting, irrespective of farm gate price or the output. On the upside, there is the potential to generate outcomes that are significantly higher than even the base case, which shows that the outgrower scheme has the potential to provide huge benefits for both the operator and the smallholder farmers. Given the strong expected return over time for both the smallholder as well as the operator, a more flexible arrangement for the financing of the working capital needs of the smallholders is required. The difficulty is created by the inability of the smallholder in some years to repay their loans when the price is low. This can arise if either the international price of paprika is low or the local currency is temporarily overvalued. This is likely to prevent the smallholders from obtaining working capital of inputs in the next year, hence the likelihood that they will exit the scheme. Perhaps if the working capital were being given in-kind by the operator to the smallholder and financed by the operator's equity, a more satisfactory outcome might result. In this way the return to the operator in the good years could be used to offset the lean years and hence a higher degree of sustainability could be achieved. As paprika is not consumed locally in significant amounts, the problem of side-selling in years when the international price is high may not be a critical problem.

The analysis also indicates that the major sources of risk are likely to be the variability in the real export price, the real exchange rate and yield rates. Yield rate fluctuations can largely be controlled through the expansion of the proportion of the total area of the scheme under irrigation. Hence, public investment policies need to be coordinated with export promotion initiatives so that there is an appropriate degree of irrigation available when the scheme starts up. Appraisals of such irrigation investments should take into consideration both the impact of irrigation on crop yields and the reduction of the variability of the cash flows accruing to the farmers and operator, which will enhance sustainability. Second, in order to lower the burden of loan financing on the scheme, such irrigation facilities might be financed as part of the public investment program of the country, 
with perhaps the amortisation of the facilities carried over a longer period of time than normal commercial loans, and paid for through water user fees charged to the farmers. In this way the overall debt burden and the rigid debt service obligations facing the smallholder could be reduced, thus also reducing the risk of default.

Third, policies should be in place at the macroeconomic level to help mitigate sharp fluctuations in the real exchange rates. For example, better sterilisation of the spikes in foreign exchange revenues in Zambia would reduce the risks facing the smallholders and operators engaged in nontraditional export crops. This might be facilitated by a revenue stabilisation fund that invests some of the additional revenues during periods of high copper prices in order to mitigate fluctuations in the real exchange rates. If Zambia wishes to expand its non-traditional agricultural exports then it must increase the effectiveness of its macroeconomic stabilisation policies in order to make its exchange rate more stable.

The integrated model of analysis demonstrates the critical role that institutional infrastructure such as supportive government policies can play in ensuring the long-term sustainability of new export crops. This conclusion is in line with those found in the recent economic growth literature that stresses the importance of developing institutional capacity for enabling production of more complex exports that would lead to better prospects for a country's economic growth (Hausmann et al., 2011). Unless the key public sector investment and macroeconomic management policies are put in place to mitigate the risks of such agriculture export initiatives, the sustainability of such potential poverty reduction programs is in jeopardy.

\section{Ednotes}

1 Zambian paprika is marketed on standards based on the European Spice Trade Association (ESTA) and is controlled for salmonella, pesticide residuals and aflatoxins.

2 Much of the international donor funding is focused on building capacity of government institutions so that they are equipped to adequately provide extension services to targeted smallholder farmers' groups in different areas of the country.

3 Cost items are classified as either tradable or non-tradable and the exchange rate applied accordingly.

4 The interest charge may also reflect the type of collateral put up by the farmer (if any), and social capital associated with the outgrower group that affects the operator's confidence in the farmers using the credit.

5 In practice, the interest rate paid by the farmer is likely to be charged by lowering the farm-gate price paid to the farmers. The application of the risk transfer to the farmer is discussed below.

6 In 2004, it was guaranteed this activity would bring farmers a net income of about US\$100 per hectare a year (African Development Bank, 2004). This is equivalent to the amount of money that the farmers would pay for the maize crop out of their earnings from a cash crop such as paprika.

7 We do not assume that purchasing power parity will hold for any given period. However, over a period of 25 years it has been shown that the cumulative changes in the market exchange rates for 85 countries are very close to the cumulative changes in the ratio of the price index of the domestic currency country to the price index of the foreign exchange country for this same set of countries (Gray \& Irwin, 2003).

8 The Zambian International currency code was ZMK by the time of writing the paper. This has been changed to ZMW through the rebasing of the kwacha by dropping the three zeros (Bank of Zambia, 2012). This paper uses the non-rebased version of the currency and will use ZMK instead of ZMW.

9 The training is limited, as it largely depends on the availability of donor funding. In order to ensure the survival of such an arrangement, the operator will need to fill the gap by providing extension services to smallholder farmers. Smallholder farmers may have limited knowledge of outgrower schemes and are likely to have very limited commercial skills to work under such arrangements.

10 The farm-gate price is agreed upon prior to the crop planting. However, the pre-planting price is subject to adjustment to reflect movements in the international export price on the global market. The process of, and mechanism for, adjusting the farm-gate price to reflect the global market is often not transparent and remains a major source of controversy, leading to side-selling of the crop by smallholder farmers. In one way or another, the operators and smallholder farmers work in such a way that they both benefit from upward movement in the export prices. In our analysis, the 17per cent is used so that the farm-gate price of paprika reflects the export price and is based on the observed farm-gate prices, which have been in the ranges of 0.8-1.2 US\$/kg (Langmead, 2005). Based on the export price of 4,500 US\$/ton, 17 per cent is deemed to be a moderate assumption and representative of what is likely to be the farm-gate price of paprika.

11 Yield rates are normally expected to decline over time, especially in a case where a given plot of land is constantly devoted to the cultivation of a single crop.

12 The annual debt service coverage ratio (ADSCR) refers to the ratio of the annual net cash flow of the project after disbursement over annual debt instalments (interest and principal) for the same period. The disbursements in this project logically reflect funding associated with the amount of annual or semi-annual incremental investments.

13 Crystal Ball Software is used to conduct the simulations and produce the statistical reports.

14 The distribution of overruns is based on experience drawn from similar operations (African Development Bank, 2004)

15 Real oil prices were used as a proxy for the fluctuations in the real costs of international transportation.

16 The capital costs of the operator for processing are expressed as an annual lease cost for buildings and equipment. 
17 This analysis assumes that any incremental investment in capital equipment for the processing of the additional paprika from this scheme will be undertaken by the operator and financed through additional equity. Such incremental capital costs are included in the processing costs of the operator (FAO, 2004).

18 The net return from growing maize includes both the opportunity cost of the farmers' labour and also their land. The farmers' land used to grow paprika should not be counted again as an additional cost.

19 Strictly speaking, the cash flow after financing adjustment represents the actual cash of the farmers. This is because the farmers do not receive the actual cash as represented by the sales at the farm-gate price, but rather an amount that is adjusted for the total credit expended on all farm inputs.

\section{References}

AFRICAN DEVELOPMENT BANK. 2004. Zambia smallholder agriculture production and marketing support project preparation report. Report No. 04/019A D B-ZAM. (African Development Bank, Tunis, 2004).

BANK OF ZAMBIA. 2012. Currency rebasing technical guidelines. (Bank of Zambia, Lusaka, 2012). Available at: http://www.boz.zm/Publishing/35/35_TechnicalGuidelines\%204-9-2012.pdf [accessed June 2014].

BERTOW, K. \& SCHULTHEIS, A. 2007. Impact of EU's agricultural trade policy on smallholders in Africa. Available at: http://germanwatch.org/handel/ euaf07.pdf [accessed June 2014].

BRÜNTRUP, M. \& PELTZER, R. 2006. Outgrowers - A key to the development of rural areas in SubSaharan Africa and to poverty reduction. (The DEG / DIE Workshop, 2006). Available at: http://www.diegdi.de/uploads/media/Outgrowers_sub-saharan-african_rural_areas.pdf [accessed June 2014].

CERVANTES-GODOY, D., KIMURA, S. \& ANTÓN, J. 2013. Smallholder risk management in developing countries. OECD Food, Agriculture and Fisheries Papers. Available at: http://www.oecd-ilibrary.org/ agriculture-and-food/smallholder-risk-management-in-developing-countries_5k452k28wljl-en [accessed June 2015].

DA SILVA, C.A. \& RANKIN, M. 2013. Contract farming for inclusive market access. Food and Agriculture Organization of the United Nations (FAO). Available at: http://www.fao.org/3/a-i3526e.pdf [accessed June 2015].

DECISIONEERING INC. 2005. Crystal Ball® 2000: User manual. Denver, Colorado, USA.

DEININGER, K. \& OLINTO, P. 2000. Why liberalization alone has not improved agricultural productivity in Zambia: The role of asset ownership and working capital constraints. World Bank Policy Research Working Paper no. 2302. Available at: http://elibrary.worldbank.org/doi/pdf/10.1596/1813-94502302 [accessed June 2015].

ECI AFRICA \& DAI PESA. 2004. Competitive analysis of the paprika in Iringa and Ruvuma. Final Report prepared for USAID (Dar es Salaam, Tanzania, 2000).

FOOD AND AGRICULTURE ORGANIZATION OF THE UNITED NATIONS (FAO). 2012. Data retrieved from FAO Statistics database. Available at: http://www.fao.org/statistics/en [accessed January 2012].

FOOD AND AGRICULTURE ORGANIZATION OF THE UNITED NATIONS (FAO). 2004. Preparation report: Zambia smallholder agriculture production and marketing support project, FAO. Investment Centre, Rome, Italy.

GLOVER, D.J. 1987. Increasing the benefits to smallholders from contract farming: Problems for farmers' organizations and policy makers. World Development, 15:441-448.

GRAY, P. \& IRWIN, T. 2003. Exchange-rate risk: Reviewing the record for private infrastructure contracts. Public Policy for the Private Sector Note 162. World Bank, Washington DC.

HAUSMANN, R., HIDALGO, C.A., BUSTOS S., COSCIA M., CHUNG S., JIMENEZ J., SIMOES A. \& YILDIRIM, M.A. 2011. The atlas of economic complexity: Mapping paths to prosperity. Center for International Development, Harvard Kennedy School and MIT Media Lab.

HAZELL, P. 2011. Five big questions about five hundred million small farms. International Fund for Agricultural Development. Available at: http://www.ifad.org/ events/ agriculture/doc/papers/hazell.pdf [accessed June 2015].

HIDALGO C.A., KLINGER B., BARABASI, A.L. \& HAUSMANN, R. 2007. The product space conditions the development of nations. Science, 317:482-487. 
KUO, C.Y., SALCI, S. \& JENKINS, G.P. 2014. Measuring the foreign exchange premium and the premium for non-tradable outlays for 20 countries in Africa. South African Journal of Economics, 83(2):269-285.

LANGMEAD, P. 2005. Appraisal of diversification opportunities: The Zambian paprika case study. AGSF Working Paper. FAO, Rome, Italy.

MAMO, S.W. 1998. Transport costs and smallholder cropping choices: An application to Siaya District, Kenya. American Journal of Agriculture Economics, 80:116-123.

MORTON, J.F. 2007. The impact of climate change on smallholder and subsistence agriculture. Proceedings of the National Academy of Sciences of the United States of America, 104:19680-19685.

ORDEN, D. 2010. Recent macroeconomic dynamics and agriculture in historical perspective. Journal of Agricultural and Applied Economics, 42:467-476.

PONTE, S. 2001. Policy reforms, market failures and inputs use in Africa smallholder agriculture. The European Journal of Development Research, 13:1-29.

PROWSE, M. 2012. Contract farming in developing countries: A review. Agence Française de Développement A Savoir. Available at: http://www.afd.fr/webdav/site/afd/shar ed/PUBLICATIONS/ RECHERCHE/Scientifiques/A-savoir/12-VA-A-Savoir.pdf [accessed June 2015].

SAKAIDA, K. 1993. Rainfall changes and their effect on maize production in Zambia. TRE Science Reports of the Tohoku University, 43:13-25.

SALAMI, A., KAMARA, A.B. \& BRIXIOVA, Z. 2010. Smallholder agriculture in East Africa: Trends, constraints and opportunities. African Development Bank. Available at: http://www.afdb.org/fileadmin/ uploads/afdb/Documents/Publications/WORKING\%20105\%20\%20PDF\%20d.pdf [accessed June 2015].

STEVENS, A. 2004. Technical report: Paprika supply chain in Zambia. USAID. Available at: http://pdf.usaid.gov/pdf_docs/PNACY603.pdf [accessed September 2011].

TINSELY, R.D. 2010. High value crops - High risk? High profit? Available at: http://lamar.colostate.edu/ $\sim$ rtinsley/HighValued.htm [accessed June 2015].

WORLD BANK. 2007. World development report on agriculture for development. The World Bank, Washington D.C. Available at: http://siteresources.worldbank.org/ INTWDR2008/Resources/WDR_00_ book.pdf [accessed September 2011].

WORLD BANK DEVELOPMENT INDICATORS. 2012. Available at: www.worldbank.org [accessed June 2015].

\section{Appendix A}

\section{The Model}

\section{Cash flows of the operator}

The net cash flows, NCBFin ${ }_{t}^{o}$, of the operator in each period $t$ are made up of a number of variables as follows:

$$
\begin{aligned}
& I N F_{t}^{o}=Q_{t}^{e} C I F_{t}+\triangle A R_{t}^{o} \\
& \text { OUTF }_{t}{ }^{o}=\operatorname{Inv}_{t}{ }^{o}+Q_{t}^{f g} P_{t}+\operatorname{Proc}_{t}+D T_{t}+\operatorname{In} T_{t}+\Delta A P^{o}+\Delta A R_{t}{ }_{t}^{f}+\Delta C B+V A T R_{t}+\operatorname{Inc}{ }_{t}^{o} \\
& \operatorname{NCBFin}_{t}^{o}=\mathrm{INF}_{t}^{o}-\mathrm{OUTF}_{t}^{o}
\end{aligned}
$$

where $I N F_{t}^{o}=$ inflows of operator from export sales; $Q_{t}^{e}=$ quantity of processed paprika exported; $C I F_{t}=$ CIF landed price of paprika; $\Delta A R_{t}=$ change in accounts receivable of export sales $\left(A R_{t-1}-\right.$ $\left.A R_{t}\right) ; O U T F_{t}^{o}=$ outflows of operator; $Q_{t}^{f g}=$ quantity of unprocessed paprika bought at the farm

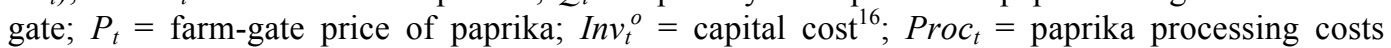
(labour + fuel + materials input costs); $D T_{t}=$ domestic transportation; $\operatorname{In} T_{t}=$ international transportation; $\triangle A P_{t}=$ change in accounts payable of operator (excluding paprika purchases) $\left(A P_{t}^{o}-A P_{t-1}^{o}\right) ; \Delta A R_{t}^{f}=$ change in accounts receivables of farmers (payable of operators for paprika) $\left(A R_{t}^{f}-A R_{t-1}^{f}\right) ; \Delta C B_{t}=$ change in cash balances $\left(C B_{t}-C B_{t-1}\right) ; V A T R_{t}=$ value added tax paid on input 
purchases $(+)$ and refunded $(-) ; \operatorname{Inc}_{t}^{o}=$ corporation income tax paid by the operator; $N C B F i n_{t}{ }^{o}=$ net cash flow of operator before financing adjustment. ${ }^{17}$

The net flows of the operator are then adjusted for the working capital loans and credit disbursements and total repayment flows between the operator and the farmers to calculate the operator's net position:

$$
\begin{aligned}
& \text { FinAdj }_{t}^{o}=\operatorname{LnBk}_{t}-\operatorname{LnOp}_{t}+\text { Rpmt }_{t}{ }^{f}-\operatorname{LnA}_{t}-\mathrm{Crd}{ }_{t}-\text { Rpmt }_{t}^{o} \\
& \text { NCFinAdj }_{t}^{o}=\text { NCBFin }_{t}+\text { FinAdj }_{t}
\end{aligned}
$$

where $\operatorname{FinAdj}_{t}{ }^{\circ}=$ financing adjustment; $L n B k_{t}=$ loan from the commercial bank to the operator; $\mathrm{LnOp}_{t}=$ loan and credit amount provided by the operator to the farmers; $\operatorname{Rpmt}_{t}^{f}=$ repayment (assuming full repayment) of loans and interest by smallholder farmers to the operator; $\operatorname{Ln} A_{t}=$ loan arrears of farmers to operators; $\mathrm{Crd}_{t}=$ credit-processing cost; $\mathrm{Rpmt}_{t}{ }^{\circ}=$ repayment of loan to bank by operator; NCFinAdj ${ }_{t}^{o}=$ net cash flow to the operator after the financing adjustment.

\section{Cash flows of the farmers}

Thus, we model the position of the farmers as follows:

$$
\begin{aligned}
& I N F_{t} f=Q_{t}^{f g} p_{t}+\Delta A R_{t}^{f}+R s d_{t}^{f} \\
& \text { OUTF }_{t}^{f}=\text { Inv }_{t}{ }^{f}+\text { LandPrep }_{t}+\text { CropM }_{t}+\text { Mnt }_{t}+\operatorname{IncMz}_{t}{ }^{f} \\
& \text { NCBFin }_{t}^{f}=\operatorname{INF}_{t}^{f}-\mathrm{OUTF}_{t}^{f}
\end{aligned}
$$

where $I N F_{t}^{o}=$ cash receipts of the farmers; $Q_{t}^{f g}=$ quantity of paprika sold through farm-gate sales ( $\gamma^{*}$ area cultivated); $\gamma=$ yield rate per hectare for the paprika crop; $P_{t}=$ farm-gate price of paprika; $\Delta A R_{t}^{f}=$ change in accounts receivable of the farmers; $R s d_{t}^{f}=$ residual value of the assets of the smallholder farmer group; $O U T F_{t}^{f}=$ total outflows from investing and operating activities of the farmers, including the farmers' opportunity costs; $\operatorname{In} v_{t}^{f}=$ investment cost of irrigation equipment and market support infrastructure; LandPrep $_{t}=$ land preparation cost (labour cost); Crop $M_{t}=$ crop management cost (labour cost); $M n t_{t}=$ maintenance cost of irrigation equipment; IncMz $z_{t}^{f}=$ income from maize forgone by farmers, ${ }^{18} \mathrm{NCBFin}_{t}^{f}=$ net cash flow of farmers before financing adjustment.

The net position of the farmers is derived by making adjustments for the medium-term loan and short-term input credit disbursements as well as their respective total interest and principal repayments, as follows:

$$
\begin{aligned}
& \text { FinAdj }_{t}=\operatorname{LnOp}_{t}+\operatorname{LnA}_{t}-\text { Rmpt }_{t}^{f} \\
& \text { NCFinAdj }_{t}{ }_{t}^{f}=\text { NCBFin }_{t}+\text { FinAdj }_{t_{19}}
\end{aligned}
$$

where $L n O p_{t}=$ loan inflows from operator; $R p m t_{t}^{f}=$ repayment of loans and interest to operator if no arrears; $L n A_{t}=$ loan arrears on repayments to the operator; $N C F i n A d j_{t}^{f}=$ net benefit flow of farmers after financing adjustment.

\section{Cash flows of the overall scheme}

The cash flow formulations for the overall contract farming scheme are as follows:

$$
I N F_{t}^{S}=Q_{t}^{e} C I F_{t}+\Delta A R_{t}{ }^{o}+R s d_{t}^{f}
$$




$$
\begin{aligned}
& \text { OUTF }_{t}{ }^{s}=\operatorname{Inv}_{t}{ }^{f}+\operatorname{LandPrep}_{t}+\operatorname{CropM}_{t}+\operatorname{Mnt}_{t}{ }^{f}+\operatorname{Proc}_{t}{ }^{o}+\operatorname{InT} T_{t}+\operatorname{Crd}_{t}+\Delta A P_{t}{ }^{o}+\operatorname{VATR}_{t}+\operatorname{Inc}_{t}{ }^{o}+\operatorname{IncMz}_{t}{ }^{o} \\
& \text { NBFin }_{t}{ }^{s}=\operatorname{INF}_{t}{ }^{s}-\text { OUTF }_{t}{ }^{s}
\end{aligned}
$$

where $I N F_{t}^{s}=$ inflows; $O U T F_{t}^{s}=$ total outflows from investing and operating activities of the scheme; $\operatorname{NBFin}_{t}{ }^{=}=$net benefit flow before financing of the scheme.

The net flows are estimated as follows:

$$
\begin{aligned}
& \text { FinAdj }_{t}{ }^{s}=\text { Grt }_{t}+\operatorname{LnOp}_{t}-\text { Rpmt }_{t}{ }^{o} \\
& \text { NFFinAdj }_{t}{ }^{s}=\text { NBFin }_{t}{ }^{s}+\text { FinAdj }_{t}{ }^{s}
\end{aligned}
$$

where $\mathrm{Grt}_{t}=$ grant financing from international donors and local grants; $L n O p_{t}=$ loan receipts from commercial banks; $\operatorname{Rpmt}_{t}{ }^{o}=$ repayment of loan to commercial banks by operator; $N F F i n$ Adj $_{t}{ }^{S}$ $=$ net benefit flows after financing adjustment. 